\title{
Teaching \& Learning Guide for: Risky-choice framing and rational decision-making
}

\author{
Sarah A. Fisher* and David R. Mandel** \\ *University of Vienna **Defence Research and Development Canada
}

This guide accompanies the following article: Sarah A. Fisher \& David. R. Mandel, 'Risky-choice framing and rational decision-making.' Philosophy Compass ... 10.1111/phc3.12763

\begin{abstract}
Authors' Introduction
An influential program of psychological research suggests that people's judgements and decisions depend on the way in which information is presented, or 'framed'. In a central choice paradigm, decision-makers seem to adopt different preferences, and different attitudes to risk, depending on whether the options specify the number of people who will be saved or the corresponding number who will die. It is standardly assumed that such responses violate a foundational tenet of rational decision-making, known as the principle of description invariance. However, recent theoretical and empirical research has begun to challenge the dominant 'irrationalist' narrative. The alternative approaches being developed typically pay close attention to how decisionmakers represent decision problems (including their interpretation of numerical quantifiers or predicate choice). They also highlight the need for a more robust characterization of the description invariance principle itself.
\end{abstract}

\section{Authors Recommend:}

Kahneman, D., \& Tversky, A. (1979). Prospect theory: An analysis of decision under risk. Econometrica, 47(2), 263-292. doi: 10.2307/1914185

This classic text critiques expected utility theory as a descriptive model of human decision making under risk. It discusses several pervasive effects that seem to be incompatible with rational choice. It develops an alternative model - prospect theory - in which value is assigned to gains and losses rather than to final assets and in which probabilities are replaced by decision weights. Prospect theory has played a central role in subsequent discussions of framing effects.

Tversky, A., \& Kahneman, D. (1981). The framing of decisions and the psychology of choice. Science, 211(4481), 453-458. doi:10.1126/science.7455683

This article marks the beginning of framing research in psychology. It introduces the central riskychoice framing paradigm, known as the 'disease problem' and presents results from a seminal set of experiments. These seem to show that people's preferences and attitudes to risk can be reversed by describing the same choice options in different ways - in terms of the number of people who will be saved or the corresponding number who will die. 
Levin, I. P., Schneider, S. L., \& Gaeth, G. J. (1998). All frames are not created equal: A typology and critical analysis of framing effects. Organizational Behavior and Human Decision Processes, 76(2), 149-188. doi:10.1006/obhd.1998.2804

This critical survey of the first two decades of framing research introduces an important three-way distinction between risky-choice framing, attribute framing, and goal framing.

Kühberger, A. (2002). The rationality of risky decisions: A changing message. Theory \& Psychology, 12(4), 427-452. doi:10.1177/0959354302012004293

This article traces the history of the 'irrationalist' narrative about framing effects and begins to present challenges to it. As such, it marks the beginning of a new approach in framing research.

Keren G. (Ed.). (2011). Perspectives on Framing. New York: Psychology Press.

This book collects papers about the mechanisms of framing effects, written from a variety of perspectives, including psychology, linguistics, marketing, political science, and medical decision making.

Teigen, K. H. (2016). Framing of numerical quantities. In G. Keren \& G. Wu (Eds.), The Wiley Blackwell handbook of judgement and decision making (pp. 568-589). Chichester, UK: John Wiley \& Sons, Ltd.

This survey article discusses the main alternative approaches to framing effects, focusing particularly on how decision-makers understand and represent numerical quantities.

Bermúdez, J. L. (2021). Frame it again: New tools for rational decision-making. Cambridge: Cambridge University Press.

This book presents interesting new philosophical arguments against the blanket view that framing effects are irrational.

\section{Sample Syllabus:}

\section{Week I: Introduction}

What are framing effects and why are they puzzling?

Levin, I. P., Schneider, S. L., \& Gaeth, G. J. (1998). All frames are not created equal: A typology and critical analysis of framing effects. Organizational Behavior and Human Decision Processes, 76(2), 149-188. doi:10.1006/obhd.1998.2804

Keren G. (Ed.). (2011). Perspectives on Framing. New York: Psychology Press. (Chapter 1)

\section{Week II: Prospect Theory}

How does prospect theory explain risky-choice framing effects and how might it be challenged?

Kahneman, D., \& Tversky, A. (1979). Prospect theory: An analysis of decision under risk. Econometrica, 47(2), 263-292. doi: 10.2307/1914185

Tversky, A., \& Kahneman, D. (1981). The framing of decisions and the psychology of choice. Science, 211(4481), 453-458. doi:10.1126/science.7455683

\section{Weeks III-IV: Numerical Quantifiers}

How do people interpret numerical quantifiers and what does this mean for framing effects?

Mandel, D. R. (2014). Do framing effects reveal irrational choice? Journal of experimental psychology. General, 143(3), 1185-1198. doi:10.1037/a0034207 
Teigen, K. H. (2016). Framing of numerical quantities. In G. Keren \& G. Wu (Eds.), The Wiley Blackwell handbook of judgement and decision making (pp. 568-589). Chichester, UK: John Wiley \& Sons, Ltd.

Chick, C. F., Reyna, V. F., \& Corbin, J. C. (2016). Framing effects are robust to linguistic disambiguation: A critical test of contemporary theory. Journal of Experimental Psychology: Learning Memory and Cognition, 42(2), 238-256. doi:10.1037/xlm0000158

Fisher, S. A. (2020). Rationalising framing effects: At least one task for empirically informed philosophy. Crítica, Revista Hispanoamericana de Filosofía, 52(156), 5-30. doi:

10.22201/iifs.18704905e.2020.1221

Fisher, S. A. (2021). Framing effects and fuzzy traces: 'Some' observations. The Review of Philosophy and Psychology. doi: 10.1007/s13164-021-00556-3

\section{Week V: Predicate Expressions}

What does a speaker's choice of predicate convey and what does this mean for framing effects?

Mandel, D. R. (2001). Gain-loss framing and choice: Separating outcome formulations from descriptor formulations. Organizational Behavior and Human Decision Processes, 85(1), 56-76.

doi:10.1006/obhd.2000.2932

Tombu, M., \& Mandel, D. R. (2015). When does framing influence preferences, risk perceptions, and risk attitudes? The explicated valence account. Journal of Behavioral Decision Making, 28(5), 464476. doi:10.1002/bdm.1863

Sher, S., \& McKenzie, C. R. M. (2006). Information leakage from logically equivalent frames. Cognition, 101(3), 467-494. doi:10.1016/j.cognition.2005.11.001

\section{Week VI: A Closer Look at Description Invariance}

What role does the principle of description invariance play in a theory of rational decision-making and in a theory of moral decision-making?

Bermúdez, J. L. (2021). Frame it again: New tools for rational decision-making. Cambridge: Cambridge University Press. (Especially chapter 4)

Sinnott-Armstrong, W. (2008). Framing moral intuitions. In W. Sinnott-Armstrong (Ed.), Moral psychology, Vol. 2. The cognitive science of morality: Intuition and diversity (p. 47-76). Cambridge MA: MIT Press.

\section{Focus Questions}

1. Should an account of risky-choice framing effects consider how decision-makers represent choice problems? What do alternative accounts (e.g. prospect theory, fuzzy trace theory, and the lowerbounding account) say about the issue of representation, and the connection between representation and choice?

2. How strong is the empirical evidence for the prospect theory account of risky-choice framing effects? Should it be defended, modified, or abandoned in favor of an alternative approach?

3. What are the points of connection/ difference between Tombu and Mandel's explicated valence account, Levin et al.'s associationist account, and Sher \& McKenzie's information leakage account?

4. What is the most plausible way of characterizing the description invariance principle? Does it apply in all decision-making contexts? 
5. What might be some other philosophical implications of the research on framing effects? How could these be explored in future work?

\section{Seminar/Project Ideas:}

Write a proposal for an experiment that would pit at least two competing accounts of framing processes against each other and that would be informative no matter how the results turn out. Clearly define the hypotheses to be tested, the independent variable or variables to be manipulated and the dependent variable or variables to be measured.

Divide the class into two debating teams (or sets of teams, if the class is large) that either argue for or against the proposition, "The findings of the original disease problem by Tversky and Kahneman (1981) demonstrate irrationality in human decision-making.” 